\title{
Ovarian-endocrine-behavioural function in the domestic cat treated with exogenous gonadotrophins during mid-gestation*
}

\author{
S. Y. W. Chan†, P. K. Chakraborty, E. J. Bass and D. E. Wildt \\ Veterinary Resources Branch, Division of Research Services, National Institutes of Health, \\ Bethesda, Maryland 20205, U.S.A.
}

\begin{abstract}
Summary. Treatment of pregnant cats with FSH on Days 33-37 and hCG on Days 38 and 39 induced development of vesicular follicles (mean 9.3 follicles/cat), ovulation (mean 3.4 corpora lutea/cat) and behavioural oestrus $(5 / 7$ cats). In the gonadotrophin-treated females, oestradiol $-17 \beta$ concentrations gradually increased but serum progesterone levels remained constant although in saline-treated females mean serum oestradiol-17ß concentrations remained basal and progesterone concentrations gradually declined. The results indicated that (1) the feline ovary and related mechanisms for inducing sexual receptivity were not refractory to exogenous gonadotrophic stimulation during mid-gestation and (2) hCG administered after serial injections of FSH during pregnancy may potentiate ovarian oestradiol-17 $\beta$ secretion.
\end{abstract}

\section{Introduction}

The domestic cat ovulates reflexly (Dawson \& Friedgood, 1940; Scott, 1970) with multiple mating stimuli eliciting one or more surges of luteinizing hormone and ovulation (Concannon, Hodgson \& Lein, 1980; Wildt, Seager \& Chakraborty, 1980; Wildt, Chan, Seager \& Chakraborty, 1981). When sterile matings result in ovulation, the cat exhibits a luteal phase of approximately 38 days in length (Shille \& Stabenfeldt, 1979; Wildt et al., 1981). During this interval mean serum concentrations of oestradiol-17 $\beta$ remain basal (Verhage, Beamer \& Brenner, 1976; Wildt et al., 1981), while progesterone values rise to a peak 14-22 days after mating and then gradually decline to a nadir by about the 42 nd day (Paape, Shille, Seto \& Stabenfeldt, 1975; Verhage et al., 1976; Shille \& Stabenfeldt, 1979; Wildt et al., 1981). The pattern of serum oestradiol-17 $\beta$ changes during pregnancy is similar to that during a sterile luteal phase, but progesterone concentrations decline more gradually during pregnancy reaching baseline about 63 days after mating, coincident with the onset of parturition (Verhage et al., 1976).

Treatment of anoestrous cats with follicle-stimulating hormone (FSH) induces development of vesicular follicles (Wildt, Kinney \& Seager, 1978b). Administration of human chorionic gonadotrophin (hCG) to queens in natural oestrus or after hormonal treatment results in follicular rupture (Wildt et al., 1978b; Wildt \& Seager, 1978). In the present study, cats were treated with these hormones in mid-gestation to determine the effects at this time.

* Reprint requests to Dr D. E. Wildt.

† Present address: Department of Obstetrics \& Gynecology, University of Hong Kong, Hong Kong. 


\section{Materials and Methods}

Eleven multiparous queens were maintained under a $12 \mathrm{~h}$ light-dark cycle and provided with food (Purina Cat Chow, Ralston Purina Company, St Louis, Missouri) and water ad libitum. Onset of oestrous behaviour was monitored daily by placing an intact, mature male with each female and observing for characteristic sexual displays (Michael, 1961; Wildt. Guthrie \& Seager, 1978a). Each queen was allowed to mate with the intact male 3 times daily throughout oestrus, and Day 1 of gestation was defined as the first day of oestrus when mating occurred.

Pregnancy was confirmed in each animal on Day 33 of gestation by abdominal palpation and laparoscopic examination (Wildt, 1980). Indications of pregnancy included the presence of a turgid, vascular uterus with distinct swollen segmentations (diameter 10-15 mm) along each uterine horn. Seven pregnant cats received intramuscular injections of FSH (2 mg/day: Burns Biotec, Oakland, California) on Days 33-37 (09:00 h) and then hCG (500 i.u./day: Organon, Inc., West Orange, New Jersey) on Days 38 and 39 (09:00 h) of pregnancy. Four additional pregnant females served as controls and received injections of saline $(9 \mathrm{~g} \mathrm{NaCl} / 1)$ at the same times. Ovarian morphology, including numbers of follicles and corpora lutea $(\mathrm{CL})$, was evaluated by laparoscopy on the mornings of Days 33 (before FSH treatment), 38 (before hCG) and 40, according to the criteria of Wildt \& Seager (1980) and Wildt et al. (1980). Blood samples (5 ml) were collected daily $(08: 30-09: 00 \mathrm{~h})$ by jugular venepuncture on Days 30-45. The females were checked daily with a male for changes in sexual behaviour, but coitus was not permitted. The length of pregnancy and litter size were recorded.

Serum samples were analysed for oestradiol- $17 \beta$ and progesterone. Assay was preceded by extraction of each serum sample with diethyl ether according to previous methods (Wildt, Panko, Chakraborty \& Seager, 1979). Quantitative recoveries of steroids ranged from $90-95 \%$ as determined from tracer added before extraction. Oestradiol $-17 \beta$ was measured by the procedure of Korenman et al. (1974) which involved use of an antiserum (GDN 244) to oestradiol$17 \beta-6-\mathrm{BSA}$ and $\left[2,4,6,7-{ }^{3} \mathrm{H}\right]$ oestradiol- $17 \beta$ as the isotope source. The interassay and intra-assay coefficients of variation were $15.4 \%(n=6)$ and $9.3 \%(n=10)$, respectively. The minimum detectable dose of oestradiol- $17 \beta$ was $4.0 \mathrm{pg} /$ tube. Progesterone was measured by the method of Koligian \& Stormshak (1977), using progesterone-11-BSA antiserum (GDN 337) and $\left[1,2,6,7-{ }^{3} \mathrm{H}\right]$ progesterone. Interassay and intra-assay coefficients of variations were $8 \cdot 9 \%(n=8)$ and $8.8 \%(n=10)$, respectively, and minimum assay sensitivity was $30 \mathrm{pg}$ progesterone/tube. Details of specificities and cross-reactivities of the oestradiol-17 $\beta$ and progesterone antisera are provided in the references of Korenman et al. (1974) and Koligian \& Stormshak (1977), respectively. The hormone results, expressed as mean \pm s.e.m., were analysed by Student's $t$ test.

\section{Results}

Laparoscopy on Day 38 revealed that all 7 gonadotrophin-injected cats produced an average of 9.3 vesicular ( $\geqslant 2 \mathrm{~mm}$ in diameter) follicles (range 6-14 follicles). Laparoscopy on Day 40 indicated that all treated cats had ovulated. The mean ovulation rate (CL/cat) and the \% of total follicles rupturing by $24 \mathrm{~h}$ after the second $\mathrm{hCG}$ injection were $3.4 \pm 0.7$ and $36.6 \%$, respectively. Overt oestrous behaviour including intense sexual receptivity was observed in 5 of the 7 females. The average duration of oestrus was 10.8 \pm 2.5 days (range 4-16 days) and began 3-6 days (Day 36-39) after the first FSH injection. No follicular development or oestrous behaviour was detected in any saline-treated female.

In the saline-treated cats mean oestradiol- $17 \beta$ concentrations remained low and consistent within a range of $10 \cdot 0-13.3 \mathrm{pg} / \mathrm{ml}$ (Text-fig. 1a). Mean progesterone levels in the same group gradually declined from a peak of $17.3 \pm 3.3 \mathrm{ng} / \mathrm{ml}$ on Day 35 to $7.5 \pm 2.1 \mathrm{ng} / \mathrm{ml}$ on Day 45 (Text-fig. 1b). In cats treated with FSH + hCG mean oestradiol- $17 \beta$ concentrations increased 


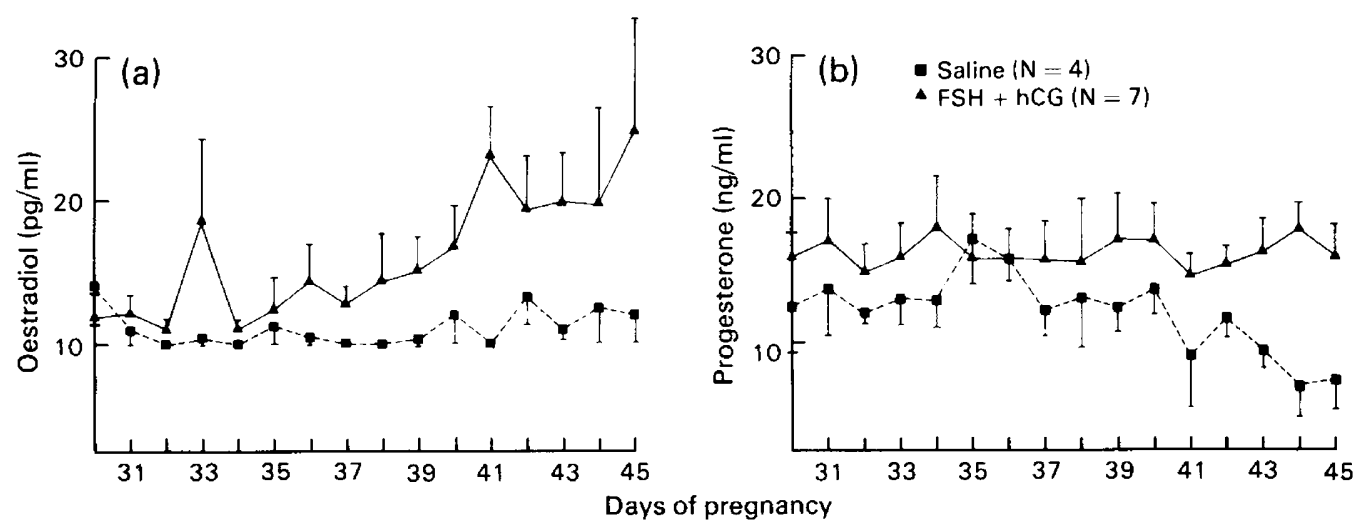

Text-fig. 1. Serum concentrations of (a) oestradiol-17 $\beta$ and (b) progesterone in cats during mid-pregnancy. Values are mean \pm s.e.m. for the numbers of cats indicated.

from Day $34(11.1 \pm 0.7 \mathrm{pg} / \mathrm{ml})$ and reached a peak value of $24.7 \pm 7.9 \mathrm{pg} / \mathrm{ml}$ on Day 45 (Text-fig. 1a); progesterone concentrations remained consistent throughout the experimental period, ranging from 14.7 to $18.1 \mathrm{ng} / \mathrm{ml}$ (Text-fig. $1 \mathrm{~b}$ ).

Comparison of the hormone concentrations in the two groups on Days 30-32, 33-37, $38+$ 39 and 40-45 showed differences only on Days 40-45; oestradiol-17 $\beta$ values were $11.8 \pm 0.7$ and $20.6 \pm 2.0 \mathrm{pg} / \mathrm{ml}$ and progesterone values were $9.8 \pm 0.9$ and $16.3 \pm 0.7 \mathrm{ng} / \mathrm{ml}$ in the saline-treated and gonadotrophin-treated animals respectively $(P<0.05$ for both).

The average duration of gestation in the gonadotrophin-treated cats was $71.3 \pm 2.7$ days (range 63-83 days) and was not significantly $(P>0.05)$ different from that of the saline-injected animals $(67.3 \pm 2.7$ days; range 63-71 days). There were also no significant differences $(P>0.05)$ in litter sizes between the former $(3.9 \pm 0.7$; range $1-6$ kittens $)$ and latter $(3.0 \pm 0)$ groups.

\section{Discussion}

The results of the serum oestradiol- $17 \beta$ measurements of pregnant cats would suggest that ovarian follicular cyclicity is suspended during gestation. However, the ovary is not refractory to exogenous gonadotrophins during mid-pregnancy because follicular maturation and ovulation were induced. Therefore, the interruption of ovarian cyclicity during gestation is probably the result of factors associated with pregnancy which may affect secretion of pituitary gonadotrophins. In this regard the cat resembles the rhesus monkey (DiZerega \& Hodgen, 1979), in which ovarian follicular development and ovulation can also be induced by gonadotrophin treatment during mid-pregnancy. Our results also indicate that associated mechanisms in the cat for triggering sexual receptivity are not refractory during mid-gestation; indeed Scott (1970) has mentioned that oestrous behaviour and mating can sometimes occur in the pregnant cat.

The response to serial injections of FSH and hCG during gestation differed from that observed during anoestrus (Wildt et al., 1978b). Treatment with gonadotrophins during anoestrus induced a shorter oestrous period (mean 6.2 days) and a greater ovulation rate (mean $10.5 \mathrm{CL} / \mathrm{cat}$ ) than were obtained in the present study. Although the feline ovary is responsive to gonadotrophins in pregnancy, the endogenous hormonal milieu may not permit complete maturation of induced follicles and so lead to reduced ovulation number.

Average serum levels of oestradiol-17 $\beta$ and progesterone in the saline-treated cats on Days 30-45 were comparable to the values reported by Verhage et al. (1976). The rise of 
oestradiol-17ß concentrations during the experiment in the gonadotrophin-treated animals confirmed the occurrence of continuous follicular growth and maturation. However, the difference in oestradiol-17 $\beta$ titres between the two groups was significant only on Days $40-45$, i.e. 1- 6 days after the 2 nd $\mathrm{hCG}$ injection. This rise in serum oestradiol-17 $\beta$ concentration could have resulted from the continued secretion of oestrogen by those follicles originally recruited by FSH treatment but failing to ovulate after hCG injections. Alternatively, hCG may have enhanced follicular maturation and potentiated ovarian oestradiol- $17 \beta$ production and secretion rates. Although hCG has been shown to be incapable of stimulating additional follicular development in the naturally oestrous cat, queens receiving 2 daily injections of hCG have significantly prolonged oestrous periods in comparison to mated, ovulating females (Wildt et al., 1978a).

Progesterone titres in the saline-treated cats declined gradually from Days 35 to 45 . In contrast, the CL induced by FSH + hCG appeared to be secretory because serum progesterone concentrations were maintained. The original $\mathrm{CL}$ of pregnancy may also have contributed to the sustained progesterone levels since hCG has been shown to stimulate, in vitro and in vivo, progesterone production by human and rhesus monkey $\mathrm{CL}$ of early pregnancy (Garner \& Armstrong, 1977; Neil \& Knobil, 1972). Neither maintenance of progesterone concentrations nor elevations in oestradiol-17 $\beta$ affected the length of gestation or litter size at term.

We thank Andrew Stewart and Patricia Schmidt for their technical assistance and Linda Fitzwater and Jane Koeser for preparation of the manuscript.

Names of commercial manufacturers and trade names are provided for identification only and inclusion does not imply endorsement by the National Institutes of Health, U.S. Public Health Service, or U.S. Department of Health and Human Services.

\section{References}

Concannon, P., Hodgson, B. \& Lein, D. (1980) Reflex $\mathrm{LH}$ release in estrous cats following single and multiple copulations. Biol. Reprod. 23, 111-117.

Dawson, A.B. \& Friedgood, H.G. (1940) The time and sequence of preovulatory changes in the cat ovary after mating or mechanical stimulation. Anat. Rec. 76, $411-429$.

DiZerega, G. \& Hodgen, G.D. (1979) Pregnancyassociated ovarian refractoriness to gonadotropin: $\mathrm{A}$ myth. Am. J. Obstet. Gynec. 7, 819-822.

Garner, P.R. \& Armstrong, D.T. (1977) The effect of human chorionic gonadotropin and estradiol-17\% on the maintenance of the human corpus luteum of early pregnancy. Am. J. Obstet. Gynec. 128, 469-475.

Koligian, K.B.\& Stormshak, F. (1977) Nuclear and cytoplasmic estrogen receptors in ovine endometrium during the estrous cycle. Endocrinology 101, 524-533.

Korenman, S.G., Stevens, R.H., Carpenter, L.A., Robb, M., Niswender, G.D. \& Sherman, B.M. (1974) Oestradiol radioimmunoassay without chromatography: procedure, validation and normal values. $J$. clin. Endocr. Metab. 38, 718-720.

Michael, R.P. (1961) Observations upon the sexual behaviour of the domestic cat (Felis catus L.) under laboratory conditions. Behaviour 18, 1-24.

Neil, J.D. \& Knobil, E. (1972) On the nature of the initial luteotropic stimulus of pregnancy in the rhesus monkey. Endocrinology 90, 34-38.
Paape, S.R., Shille, V.M., Seto, H. \& Stabenfeldt, G.H. (1975) Luteal activity in the pseudopregnant cat. Biol. Reprod. 13,470-474.

Scott, P.P. (1970) Cats. In Reproduction and Breeding Techniques for Laboratory Animals, pp. 192-208. Ed. E. S. E. Hafez. Lea \& Febiger, Philadelphia.

Shille, V.M. \& Stabenfeldt, G.H. (1979) Luteal function in the domestic cat during pseudopregnancy and after treatment with prostaglandin $\mathbf{F}_{2 \alpha}$. Biol. Reprod. 21, 1217-1223.

Verhage, H.G., Beamer, N.B. \& Brenner, R.M. (1976) Plasma levels of estradiol and progesterone in the cat during polyestrus, pregnancy and pseudopregnancy. Biol. Reprod. 14, 579-585.

Wildt, D.E. (1980) Laparoscopy in the dog and cat. In Animal Laparoscopy, pp. 31-72. Eds R. M. Harrison \& D. E. Wildt. Williams \& Wilkins, Baltimore.

Wildt, D.E. \& Seager, S.W.J. (1978) Ovarian response in the oestrual queen receiving varying dosages of HCG. Horm. Res. 9, 130-136.

Wildt, D.E. \& Seager, S.W.J. (1980) Laparoscopic determination of ovarian and uterine morphology during the reproductive cycle of the cat. In Current Therapy in Theriogenology, pp. 828-832. Ed. D. Morrow. Saunders, Philadelphia.

Wildt, D.E., Guthrie, S.C. \& Seager, S.W.J. (1978a) Ovarian and behavioural cyclicity of the laboratory maintained cat. Horm. Behav. 10, 251-257. 
Wildt, D.E., Kinney, G.M. \& Seager, S.W.J. (1978b) Gonadotropin induced reproductive cyclicity in the domestic cat. Lab. Anim. Sci. 28, 301-307.

Wildt, D.E., Panko, W.B., Chakraborty, P.K. \& Seager, S.W.J. (1979) Relationship of serum estrone, estradiol-17 $\beta$ and progesterone to $\mathrm{LH}$, sexual behavior and time of ovulation in the bitch. Biol. Reprod. 20, 648-658.

Wild, D.E., Seager, S.W.J. \& Chakraborty, P.K. (1980)
Effect of copulatory stimuli on incidence of ovulation and on serum luteinizing hormone in the cat. Endocrinology 107, 1212-1217.

Wild, D.E, Chan, S.Y.W., Seager, S.WJ. \& Chakraborty, P.K. (1981) Ovarian activity, circulating hormones and sexual behavior in the cat. I. Relationships during the coitus induced luteal phase and the unmated estrous period. Biol. Reprod. 25, $15-28$.

Received 9 September 1981 